\title{
Post-Harvest Loss and Grain Storage Technology- A Review
}

\author{
Bayode Julius Olorunfemi ${ }^{1, a, *}$, Sunday Emmanuel Kayode ${ }^{2, b}$ \\ ${ }^{1}$ Department of Mechanical Engineering, Faculty of Engineering, Federal University Oye Ekiti, Nigeria \\ ${ }^{2}$ Department of Agricultural Engineering, School of Engineering, Federal University of Technology, Akure, Nigeria \\ *Corresponding author

A R T I C L E I N F O A B S T R A C T \\ Review Article \\ The aim of this write up is to explore technological developments in the area of post-harvest grain \\ storage techniques. Post-harvest losses occur between harvest and the moment of human \\ consumption. They include on-farm losses, such as when grain is threshed, winnowed, and dried, \\ as well as losses along the chain during transportation, storage, and processing. Use of traditional \\ Received : 01/07/2020 \\ Accepted : 05/08/2020 \\ grain storage facilities such as cribs, improved rhombus, and brick bins are ineffective against mold \\ and insects already present in the grain before storage. While plastic bins reduce insect pests' \\ infestation, Purdue Improved crop storage bags and wooden silo were proved to be a viable \\ management tool for preventing aflatoxin accumulation in storage and moisture migration. The \\ metal silo still remains an effective grain storage technology for reducing post-harvest insect and \\ pathogen losses if the challenges of moisture and temperature can be adequately managed. An \\ effective grain storage technology would be the ones that can sustain quality of grain stored for a \\ long period ( $\geq 5$ years), durable, cost-effective, and be managed scientifically, possibly by computer- \\ Keywords: \\ Loss \\ Moisture \\ Temperature \\ aided grain management system. \\ Prevention
}

\section{Introduction}

In September 2015, the United Nations (UN) ambitiously announced a goal of halving worldwide food waste and substantially reducing global food loss by 2030 as part of its Sustainable Development Goals (SDG) agenda (Sheahan and Barrett, 2017). While the vision in the transformation strategy of the present government of Nigeria is to achieve a hunger-free Nigeria through agricultural sector that drives income growth, accelerates achievement of food and nutritional sector, generates employment and transforms Nigeria into a leading player in global food markets to wealth for millions of farmers (ATA, 2012).

Post-harvest losses estimated by UNIDO (1979) to be from 20 to $40 \%$, storage losses alone are $5 \%$ while food losses are estimated to be from 10 to $60 \%$ depending on the type of food material (Igbeka, 2013). A study by Fox and Fimeche (2013) reported that current agricultural practices use 4,931 million hectares of the total 14,894 million hectares of land surface on the earth. In addition, agricultural production uses 2.5 trillion $\mathrm{m}^{3}$ of water per year and over $3 \%$ of the total global energy consumption, and with estimated food losses of about $30-50 \%$ of total production. This translated to wasting 1.47-1.96 Gha of arable land, $0.75-1.25$ trillion $\mathrm{m}^{3}$ of water and 1-1.5\% of global energy. Food losses can be quantitative as measured by decreased weight or volume, or can be qualitative, such as reduced nutrient value and unwanted changes to taste, color, texture, or cosmetic features of food (Hodges et al., 2011). Every unit of product saved from post-harvest losses translates into an added unit available for productive utilization, including household consumption, at a time when global food security is under threat from shrinking arable land and variation in climate change (Mbata, 2013).

Hodges (2013) reported that cereal grains are the main food staples of Sub-Saharan Africa (SSA). Losses after harvest of both quantity (weight losses) and quality deprive farmers of the full benefits of their labours, and that for Eastern and Southern Africa the value of this weight loss amounts to about 1.6 billion US dollars (USD) per annum, or possibly about four billion USD for all of sub-Saharan Africa. Adopting cost-effective technologies could help smallholders in Sub-Saharan Africa tackle postharvest losses and increase their income. According to the FAO, post-harvest losses reduce the income of the continent's farmers and value chain actors that depend on farmers by about $15 \%$. 


\section{Post-Harvest Grain Losses}

Post-harvest losses are a major cause of concern worldwide where below 5\% research funding has been allocated (Rajashekar et al., 2012). Grain losses in maize for example can reach 20-30 \% under reasonable conditions. This sort of loss lowers the income and standard of living of farmers and also leads to waste of a large fraction of the contribution to the nation's food supply (Asiedu and Van Gastel, 2001). There are different types of losses in grains and other storage materials during their storage periods. These include; weight loss, quality loss, colour loss, value loss, and organoleptic loss (Talabi, 1996).

The process of grain deterioration is primarily driven by aerobic respiration of fungi as they consume carbohydrates in the kernel giving of $\mathrm{CO}_{2}, \mathrm{H}_{2} \mathrm{O}$ and heat. Mycotoxins are produced by some types of storage mould. The common types which pose a risk to human and animal health are: Deoxyvalenol, Ochratoxin, Aflatoxin, Zearalenone, Fumonisin (Ileleji, 2010). Mycotoxin contamination of feeds and food has been examined over the past 30 years from several perspectives (Abramson, 1991). Fungi activity during storage of grain and grain products can result in change in carbohydrates, protein, lipids and vitamins (Bothast, 1978). Fungal activity on grain could lead to, decrease in germination, discolouration of the germ, heating or mustiness, decrease in nutrient value and loss of weight. Growth of moulds in cereal grain leads significant changes of lipids, faster when moisture increases (Opit, 2009). Hassan et al. (2009) reported that ethno botanical research has documented traditional uses of plants, while studies by natural product chemists and ethno botanists have revived that these plants may be used to protect agricultural crops (pre- harvest and post- harvest) from insect herbivory.

It is best to detect fungal deterioration of cereals in storage at an early stage, when intervention procedures are still feasible and economical. When heating, caking and sprouting become conspicuous, irreversible quality loss has occurred (Abramson et al., 1991). Ileleji (2010) reported that the conditions for the optimum growth of storage moulds must be controlled by ensuring that the grain moisture content (interstitial water activity) be low at low $\mathrm{RH}(<65 \%)$, temperature $\left(10^{\circ} \mathrm{C}\right)$, and that the grain should be intact with less damage and dusts.

During post-harvest handling of produce, mechanical damage can be inflicted on the food, causing the enzymes contained in the cell tissues to be released. These enzymes begin to break down the cellular material and the chemical reactions initiated by the enzymes result in the loss of flavour, nutrients, colour and the deterioration of texture (Mbata, 2013). Since enzymes are mainly composed of protein, they are sensitive to heat, therefore if temperatures are not controlled during post-harvest handling this may cause the produce to deteriorate at an accelerated rate. Cereal grains and oilseeds are hygroscopic. They lose moisture when exposed to dry air or gain moisture when exposed to wet air until equilibrium is reached. The weather, primarily the air vapour mixture properties determine strategies for drying and storability of a particular grain type. (Calderon and Barkai-Golan, 1990).

\section{Historical Developments in Storage Technology}

Post-harvest storage technology can be said to be the most important aspect of food production. Post-harvest technologies can contribute to food security in multiple ways. They can reduce post-harvest loss, thereby increasing the amount of food available for consumption by farmers and poor rural and urban consumers, thus improving their food security (Kiaya, 2014). The use of commodity storage is an ancient idea. For instance, the Egyptians operated an ever- normal granary, storing food during the seven years of plenty and then releasing these during the Seven years of famine (Holy Bible, 2008).

Hermetic storage of grain was practiced in ancient times in underground pits in the dry, subtropical regions of the Middle East and other dry regions of the world, such as Africa and India. Novarro et al. (1999) carried out several researches on hermetic paddy in bags using storage of GrainPro Cocoons of 300-ton capacity (Figure 1). Underground pits for grain storage was still used in Egypt in the 1940s, as described by Attia (1948). Very old but active hermetic storages were reported to be in operation in India (Girish, 1980) and in Yemen, Somalia, Sudan, and Egypt (Kamel, 1980). It has been suggested that, in Biblical times, Joseph employed hermetic storage for the preservation of the large grain reserves in Egypt during the seven years of plenty (Calderon and Barkai-Golan, 1990). Classical China also operated commodity buffer stocks, particularly under the consolidation during the Sui dynasty in the $7^{\text {th }}$ century (Daudu et al., 2013).

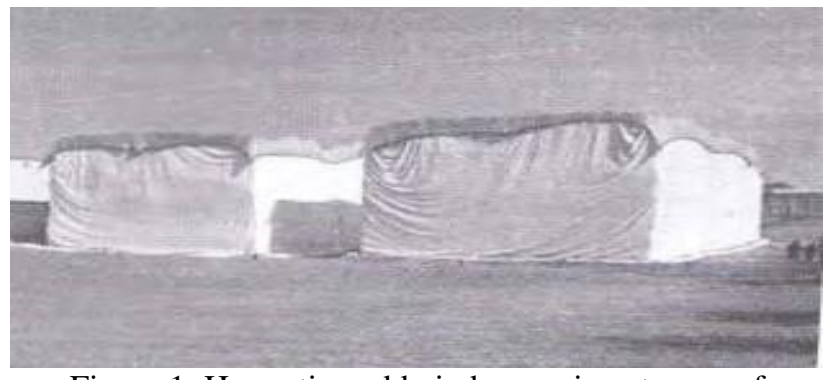

Figure 1. Hermetic paddy in bags using storage of GrainPro Cocoons of 300-ton capacity

Traditional methods of managing grain have not guaranteed no loss, instead losses range from 20-50\% (Talabi, 1996). The results of detailed field studies suggest that under traditional storage systems in tropical countries, losses are typically around $5 \%$ over a storage season (Tyler and Boxall, 1984) depending upon the crop, the ambient conditions, the period of storage and other factors. It is strongly believed that the major problem militating against food security in Nigeria is not the production but postharvest operations (Mijinyawa, 2006). Odigboh (2004) expressed the same concern about post- harvest losses. A 5 $\%$ loss level should not however be considered insignificant.

It should be noted that physical losses are usually accompanied by qualitative losses affecting the mass of the grain in store. Secondly the losses are mainly experienced during the lean season before the new harvest is ripe, thereby having an adverse effect on the food security of farming families at a particularly critical period. 
Greeley (1987) reported that in Honduras, farmers' feelings of insecurity about this period have been an important motive for adopting metal storage bins. Even where detailed studies are undertaken, there are several methodological difficulties involved in estimating losses. Loss assessment methods tend to be slow and to require skilled field and laboratory staff. They are often undertaken on experimental sites, making it difficult to relate the results to on-farm situations (NALEP 2004).

Udoh et al. (2000) classified storage techniques into three categories namely: Traditional/ local grains storage techniques at farm and domestic level which includes local cribs and rhombus, platform, open field, roof and fireplace (These types of storage structure are suited for maize grain stored intact with cobs in ears); Improved/semi modern grains storage techniques at farm and domestic level which are the ventilated cribs, improved rhombus, and brick bins and modern centralized storage at commercial level which includes silos and warehouses are well reported (Igbeka, 1983; FAO, 1994; Okunade, 2013). Grain storage bins made of steel net and wire mesh are also common maize storage options for smallholder farmers in China and Central America (Shengbin, 2006).

\section{Materials and Methods}

Improved traditional storage methods: On-farm storage system is the locally and adaptive storage system that farmers use traditionally right in their farm centers. It is the most appropriate storage system for farmers except for all their short comings. There storage capacities are very small, between 0-5 tons. They are majorly traditional, cheap and adaptable technologies (Igbeka and Olumeko, 1996). The storage and preservation facilities used in this system include; local barns, ceiling roofs, fire points, treetops, air tight potteries, wooden frames or structure and dry room stores. The indoor and outdoor storage structures can be classified under the locally traditional on-farm storage system. Some researchers have worked on the possible introduction of modified atmosphere technology to grain storage (Banks and Annis, 1980; Jay, 1984; Navarro et al., 1988).

Reinforced brick masonry structure: This is an outdoor structure with capacity of 3.5 tons. It is constructed from bricks that have been reinforced using mild steel bars. In this design, two brick masonry walls of $1200 \mathrm{~mm}$ thickness are constructed, and a polythene sheet is placed between the walls to moisture- proof.

The improved rhombus: The improved rhombus is constructed on a circular base of burnt bricks of 0.75-1.0 ton above the ground. The design of the improved mud rhombus incorporates the basic of the design of the mud rhombus found in the northern region of Nigeria. The design however takes care of the fault inherent in the design and as much as possible tries to eliminate them.

The underground brick masonry structure: is an outdoor structure that is circular in shape. As the name of the structure, it is constructed below the ground, although the upper part of the structure is above the ground. The structure has the capacity of 5.0 tons and is constructed of bricks that are laid in cement mortal.

The underground reinforced cement concrete structure is an outdoor structure constructed of reinforcement concrete. It is circular in shape and has a capacity of 3.5 tons. As the name implies, it is constructed below ground level except for its upper part which is constructed above the ground.

The reinforced cement concrete ring bin- the reinforced cement concrete ring bin is an outdoor structure that is circular in shape. The structure is provided with a base that is about $0.75-1.0$ ton above the ground. The structure is constructed from a mould that has a height of one foot. The mould consists of inner and outer lay that are separated by spacer.

The indoor brick masonry structure- the indoor brick masonry structure is an indoor structure that is rectangular in shape. The structure has two compartments each of one metric ton capacity; the structure could therefore be used for the storage of different grain. Natural farm waste fuel crop dryer has a batch holding capacity of $124-150 \mathrm{~kg}$. Continuous movement of hot air through the wet grain takes place leading to drying.

Indoor metal bins- indoor metal bins as the names implies are indoor structure. They are circular in shape and are fabricated from galvanized iron sheet that are available in the following capacity; $200 \mathrm{~kg}, 300 \mathrm{~kg}, 400 \mathrm{~kg}$, and 1.0 ton metal bin. Reducing postharvest losses during storage of grain crops to strengthen food security in developing countries reducing postharvest losses during Storage of grain crops to strengthen food security in developing countries

$175 \mathrm{~kg}$ modified oil drum- the structure is an indoor structure similar to metal bin. It is circular in shape and is constructed using an empty old drum. Like the metal bin it has an inlet with cover at the bottom. The inlet or outlet and their covers are fabricated with galvanized iron sheet.

Crib- Crib under the traditional system, harvested grains are being stored either around the fire place (local cooking area) or on- the farm-ground and covered with stalk or sorghum/corn. These two systems are for small scale storage. The formal has the disadvantages of discolouring the grains, and hence the market value/ quality, reducing or even totally killing the viability of the stored grains. The latter exposes the grains to thieves, over drying and attack by pests like insects and rodents. Crib could be used in regions where grains are grown more than once in a year especially in southern part of Nigeria or northern Nigeria under the River Basins Development Authorities. The rectangular-shaped structure is built in such that the length could be as long as even $10 \mathrm{~m}$ but the width should not be more than $1.5 \mathrm{~m}$ and placed at right angle to the prevailing wind direction. The legs are raised about $1.0 \mathrm{~m}$ above the ground and provided with rat guards to prevent rodent attack.

Improved Rhombus- The traditional rhombus commonly used before is made of straw/basket. This can easily be attacked by rodent, termite, flood, fire, and so on. Moreover, it is not strong at all. However, there is an improved rhombus which has the following features. Short pole provided to raise the rhombus above the ground to prevent flooding and rodent attack. Small opening for loading the grains instead of entering inside under the traditional system. Rodent guard provided on the shortpoles to prevent entry by rodent and other pests. Improved rhombus could keep un-threshed grains (that doesn't require further drying) in good condition for 6-9 months. 

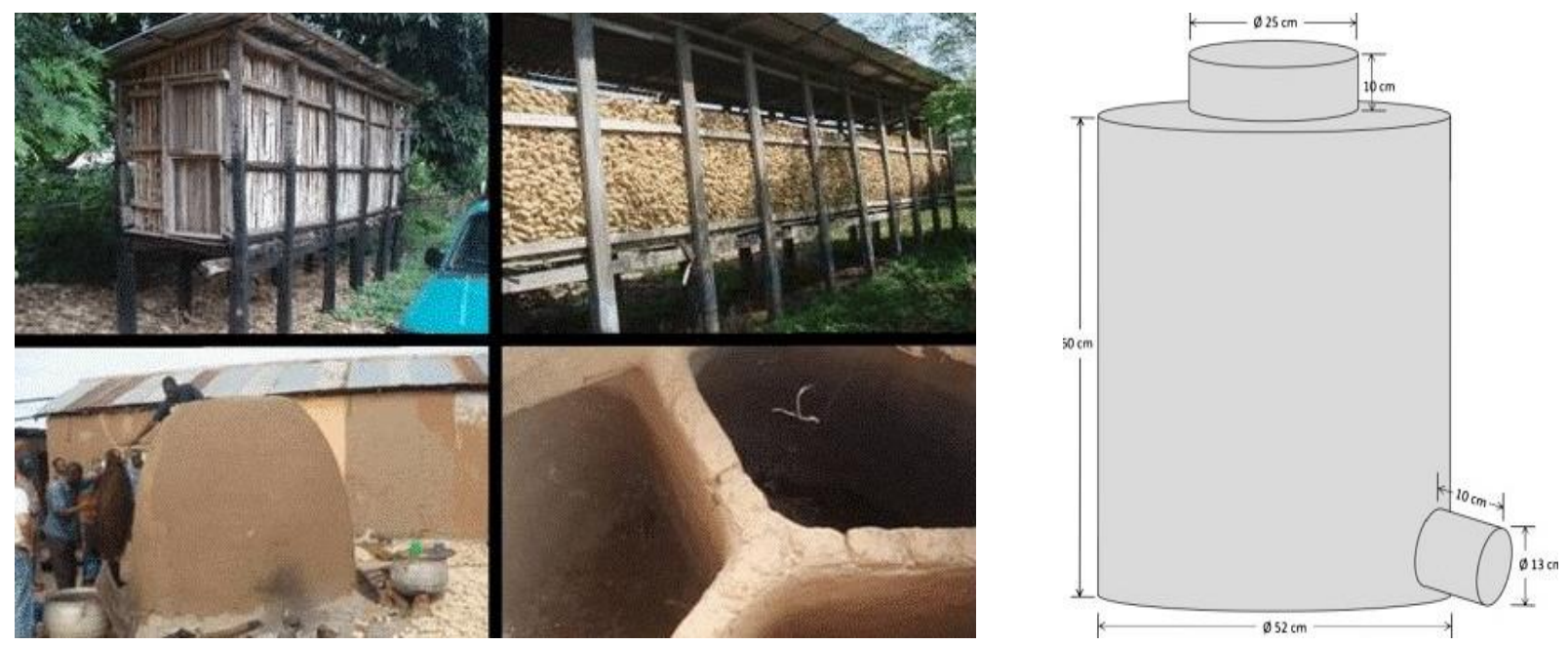

Figure 2. Some improved traditional storage technologies

\section{Results and Discussions}

\section{Modern Storage Techniques}

The report by the International Food Policy Research Institute released recently highlights the scale of postharvest losses and the gains farmers could make by using novel technologies such as Purdue Improved Cowpea Storage (PICS) bags, metal silos and zero energy cool chamber (ZECC) (Baral and Hoffmann, 2018)). It can be clearly observed that losses in all new storage techniques were significantly lower than those in the traditional storage, with the minimum being in the case of metallic silos. A nationwide study on post-harvest losses of rice in China reported 7-13\% grain losses at the rural household storage facilities, compared to only $0.2 \%$ losses at the national reserve level using scientific storage structures (WeiFen and ZuXun, 2003).

\section{Plastic Bins}

Bosomtwe et al. (2020) worked on the evaluation of plastic bins for protection of stored maize against insect infestation in Ghana. Untreated maize pre-disinfested with a solar biomass hybrid dryer was stored in either a 7tons white plastic bin or a 7 tons' green plastic bin, or a 6 tons' steel bin as experimental treatments. The results of their study showed that plastic bins reduce insect pests' infestation of stored maize and therefore have the potential for use in short to long term storage of grains.

\section{Purdue Improved Crop Storage (PICS) Bags}

PICS bags are a three-layer, hermitic bag-system that forms a barrier against the influx of oxygen and the escape of carbon dioxide (Figure 2). William et al. (2014) carried out research on the use of PICS bags. The results of the study demonstrated that storage of maize in PICS bags is a viable management tool for preventing aflatoxin accumulation in storage. It also established that PICS create barrier to external moisture, preventing rewetting or drying. PICS bags use a triple-bagging hermetic storage technology (Figure 3), and are used extensively in Africa and Latin America (De Bruin et al., 2002).

\section{Wooden Silo}

The performance of wooden silo for long-term (wet and dry seasons) storage of maize (Zea mays) under tropical climate was evaluated by Alabadan (2006). The results showed that there were no incidences of moisture condensation within the silo. The structure possessed adequate structural integrity except for slight incidences, colour change, delaminating and peelings of sheathing materials.

\section{Metal and Concrete Silo}

The choice of construction material is usually between steel and concrete, though in some countries timber or masonry is still used as alternatives. The choice between steel and concrete is dependent on several considerations, all of which ultimately come down to capital and operational costs. The fact that in most countries, steel and concrete are both so widely used indicates that these costs are generally not dissimilar. Kimenju and de-Groote (2010) conducted an economic analysis of using advanced storage structures and reported that the economic gain (extra income by avoiding losses) using a metal silo compared to polypropylene bags could be up to USD 100 per ton of grains after 12 months of storage. Figure 4 shows an example of a cluster metal silo for storage of grains.

The dreaded condensation phenomenon in steel silos usually occurs when temperature of the dry but warm product is higher than that of outside. As a result of this, the inner side of the silos is cooled to a temperature which is lower than the dew-point of air. This leads to the formation of a film of water on the metal wall (Ileleji, 2009; Igbeka, 2013; Olorunfemi, 2015). Accordingly, the granules become attached to the wall and some of them start to drop. The greater the difference in the temperature of the grain and outside air, the greater the volume of water extracted. Proprietary bins made from light gauge bolted steel panels are a low-cost storage option. They can be difficult to seal adequately for fumigation due to the large number of bolts required for sealing $(8,000-10,000$ pieces $)$ for a silo of 1000 tons (Roblodo, 2005). 
The metal silo still remains an effective grain storage technology for reducing post-harvest insect and pathogen losses in maize while improving smallholder farmers' food security in developing countries (Tefera et al., 2011).

\section{Volcani Cubes}

Volcani cubes (GrainPro cocoons) are made of flexible PVC liner with airtight zippers and can be supplied in capacities of $5,10,20,50,100$ or 150 tons of grains in carrying bags. This storage structure can be used in the storage of maize (Novarro et al., 1988). The concept behind this product was known and utilized, since ancient days by our ancestors in many ways. It is based on the simple fact that without oxygen $\left(\mathrm{O}_{2}\right)$ and with the increase of carbon dioxide $\left(\mathrm{CO}_{2}\right)$, no insect could survive, Volcanic Cubes systems do just that. The Volcanic Cubes are the fruits of an extensive research, utilizing the recent technologies in Polymers Engineering. The system has proven to be waterproof, gas tight, hermetically sealed, and Rodent resistant. The Volcanic Cubes could quickly be erected anywhere, in the field or where proper shelter is not available, at grassroots levels. Cocoons are widely used in Rwanda, Ghana, and the Philippines for storing both shelled and unshelled corn, (Novarro, et al., 1999).

\section{The Frig-O-Dry Storage and Preservation System}

The Frig-O-Dry storage and preservation system is an update or improved version of modern metal silo system currently in use in most parts of the world. The Frig-O-Dry system designed and developed to operate under any ambient conditions around the world using its computerized regulatory (controlled) cooling mechanism. In this method, ambient air is cooled and then passed over the bulk grains via existing aeration system (Navarro and Noyes, 2002). The main reason for grain rotting is self -heating of the products in countries with a temperate climate, example is found in Central-Europe during autumn and winter, then in the hot months during and immediately after the harvest. In addition to a significant reduction in the drying costs, minimization of respiratory losses and maintenance of best quality. Cold preservation of grains offers excellent protection against insect activity (Figure 5). Frig-O-Dry system is installed at the National Grain Silo Complexes at Okuku-Ogoja, and Lafiagi both in Nigeria for the storage of maize, sorghum and beans (Olorunfemi, 2014). Cold preservation of grains offers excellent protection against insect activity. These losses can be reduced considerably by cold preservation with Frig-O-Dry grain chillers. This system is more suitable for tropical countries.

\section{Recommendations and Way Forward}

The modern-day storage facilities employ innovative technology in terms of choice of material, durability, and management. The Management system to be adopted for a storage structure depends on several factors including the type of structure, size of structure and material of all storage structures. Application of computer monitoring system will help to facilitate the introduction of planned maintenance schedules for all installed silo equipment (Ajisegiri and Obafisoye, 2005). Arthur et al. (2001) asserted that Computers are an ideal platform to model grain storage management systems and that, this can be utilized to study the physical and biological parameters involved in the grain storage and established realistic operating parameters to implement monitoring practices. In addition, Computer aided management would ensure timely registration of goods; enhance human efficiency and effective managerial decisions (Olorunfemi et al., 2015).

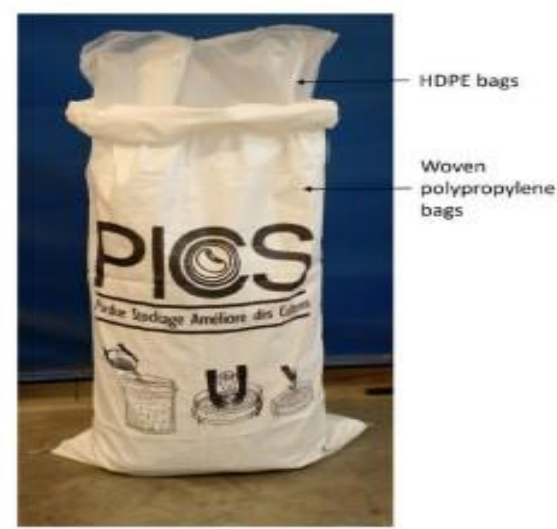

Figure 3. Triple-bagging hermetic storage for developing countries.
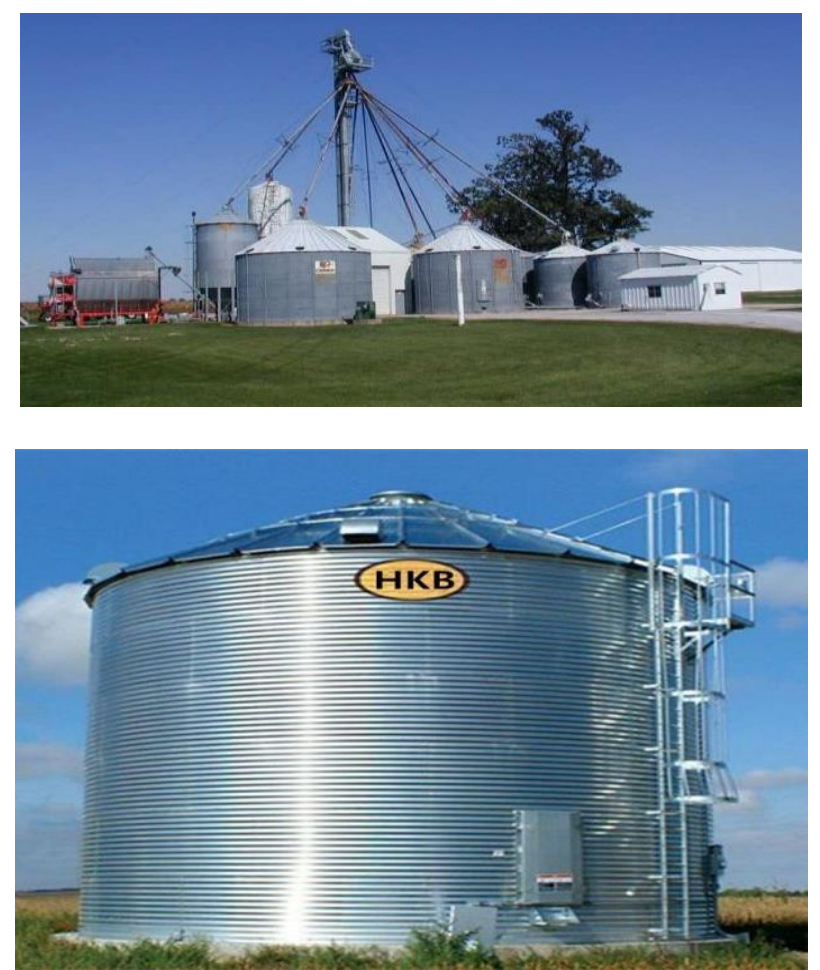

Figure 4. Cluster of metal silo system (Ileleji, 2013)

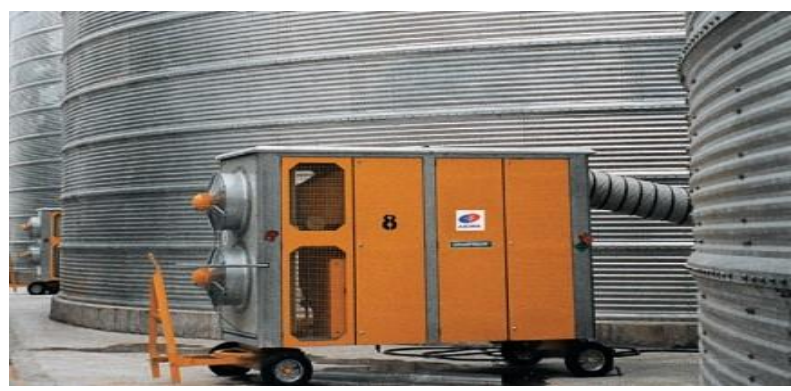

Figure 5. GRANIFRIGOR ${ }^{\mathrm{TM}}$ grain cooling in steel silos (Brunner, 1989) 


\section{Prepare Grain Bins}

The first step for quality grain is to make sure that storage facilities are prepared for the grain going in. Bins must be cleaned by getting rid of any grain left that might have insects in it. Also, floor areas should be check. With the use of moisture meter (example is MT pro), the dryness of the grain must be monitored. Agreed safe percentage of moisture content of different grains (dry basis) are: maize $(\leq 12 \%)$, wheat $(\leq 13 \%)$, sorghum $(\leq 13 \%)$, cowpea $(\leq 12 \%)$, and rice $(\leq 12 \%)$ (Mushira, 2005; Ileleji, 2013; Igbeka, 2013; Olorunfemi, 2015).

\section{Store Quality Grain}

The quality of grain stored can only be maintained but not improved on during storage (FAO, 1994). Hence, good quality grain must be ensured at the reception of the grain. Laboratory analyses of samples of the grains to be stored must be carried out to ensure no loss. The parameters for grain before reception were $1 \%$ broken grain, $1 \%$ mould, $1 \%$ foreign matters, $68-75 \mathrm{~kg} / \mathrm{hl}$ weight and $12 \%$ moisture content ((Navarro et al., 1999; Ajisegiri and Obafisoye, 2005; McNeill, 2010).

\section{Dry to The Right Moisture Content}

McNeil (2010) came up with standard equilibrium moisture content (EMC) for maize and soybean. This is applicable in the United State and regions of the same climatic condition, as well as in Nigeria. He reported that, it is unsafe to store grain at the temperature of $15^{\circ} \mathrm{C}$ when the EMC [ $(\%$ wb (wet basis)] was $15 \%$ or more, or when the temperature is $40^{\circ} \mathrm{C}$ and $13 \%$ EMC. The safe storage EMC \% wb is $11.5-13$ if the temperature is between $20-40^{\circ} \mathrm{C}$.

\section{Operate Modified Atmosphere}

Aeration is very important for good grain storage as it helps to maintain uniform grain temperatures, minimizes moisture migration, and prevents quality loss of stored grain. The temperature of grain stock is monitored with the aid of temperature sensors installed inside the silo bins. Modified atmospheres (MA) and controlled atmospheres (CA) offer alternative to the use of conventional residue producing chemical fumigants for controlling insect pests attacking stored grain (Figure 6). However, when grain is clean, sound and at moisture content of $\leq 12 \%$, where all the metabolic activities, such as respiration are extremely low and in this way the grain is dormant and stores very well (Maier et al., 1997; Warrick, 2010).

\section{Closed Loop Fumigation Facility}

Noyes et al. (1995) worked on the use of closed loop fumigation (CLF) as against the traditional application of phosphine fumigants. The use of low horsepower 'closed loop' fumigation system is an alternative to improving phosphine fumigant distribution and reducing fumigation failures. Closed loop systems involve the use of a simple low pressure, low volume centrifugal blower which draws the fumigant or air mixture from the head space of the structure and pushes the gas into the base of the structure, forcing it to flow upward through the grain into the head space in a closed loop cycle. A drawing of a CLF system on a round grain bin is shown in Figure 7 (Ileleji, 2013).
In a properly designed and constructed system, closed loop systems work best in concrete silos and large welded steel tanks. A closed-loop fumigation (CLF) system can be added to many grain storage structures to speed up the distribution of phosphine gas and make the concentration more uniform throughout (Noyes et al., 2002). Benefits of CLF system included; reduced worker exposure; quicker fumigation response time; lower operating cost for fumigants through reduced labour and possible lower fumigant requirement; reduced regulation compliance costs; and potentially better fumigation efficacy with the same management expertise (Noyes and Kenkel, 1993).

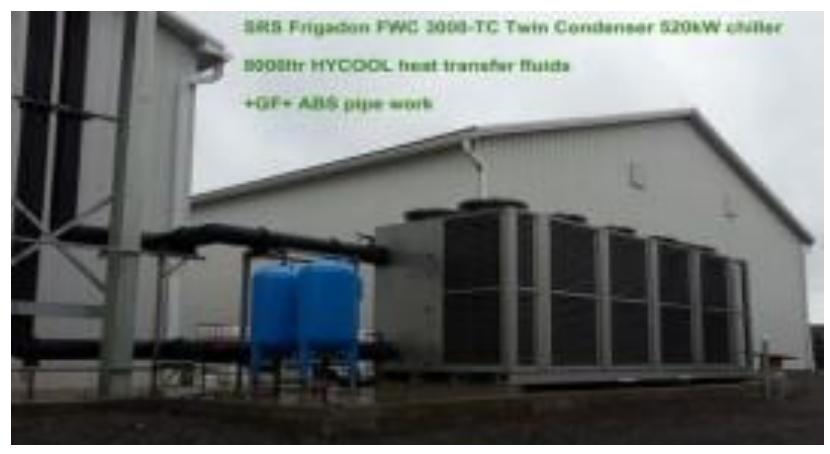

Figure 6. Controlled atmosphere

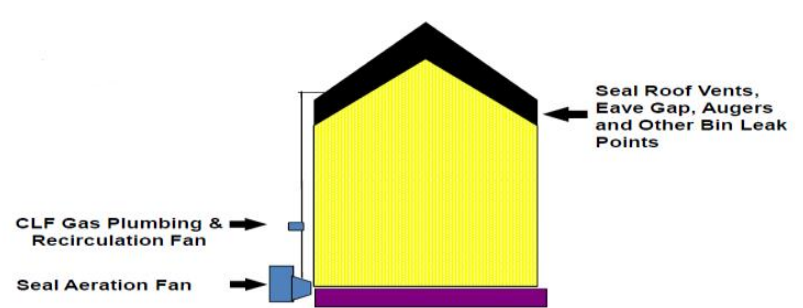

Figure 7. CLF system on a typical round grain bin. Arrows represent airflow path

\section{SLAM Post-Harvest IPM Strategy}

The Sanitation Loading Aeration Monitoring (SLAM) post-harvest Integrated Pest Management (IPM) strategy is a system approach to maximize grain quality. Its success depends on the proper selection of crop varieties, production and harvest practices, grain handling equipment, drying systems, and storage management (Mason and Woloshuk, 2010). SLAM represents four simple steps- sanitation, loading, aeration, and monitoring. It is the objective of SLAM to maintain maximum postharvest quality by protecting stored grains and oilseeds from weather, rodents, insects, self-heating, molds, mycotoxins, and pesticide residues.

\section{Control The Temperature}

The ability to control the temperature of grain during storage is very important. Although controlled atmosphere (CA) treatment of grain is an old and proven technology, its applications remained limited (Navarro, 2006). A storage system that has a good aeration system must be installed to control the grain temperature (Igbeka, 2013). Use of computer aided monitoring system will be of necessity for proper evaluation of the condition of grains in storage. The other important aspect of this is temperature 
cables to be installed in the silos. Temperature cables provides valuable information for isolated spots inside grain bins, especially where handheld grain sampling probe cannot collect samples and temperature probes could not penetrate the grain bulk, this was also reported by Maier (2002). Mushira (2005) recommended that should the temperature increase rapidly by more than $2{ }^{\circ} \mathrm{C}$, the entire stock in the silo must be re-cycled. Sufficient exposure to different temperature and relative humidity would dry grain to the moisture as indicated. Experience has showed that stored grain moisture decreases with increase air temperature.

\section{Computer-Aided Monitoring System}

It is widely reported that Computers are an ideal platform to model grain storage management systems and that, this can be utilized to study the physical and biological parameters involved in the grain storage and established realistic operating parameters to implement monitoring practices (Arthur et al., 2001; Olorunfemi, 2014). In addition, Computer aided management would ensure timely registration of goods; enhance human efficiency and effective managerial decisions (Olorunfemi et al., 2015).

\section{Conclusion}

It is said that a grain saved is as good as an additional grain produced. concerted efforts should be made in reducing post-harvest loss to the barest minimum. With the current efforts of international organizations (WHO, FAO) on chemical insecticides to be phased out or drastically reduced as a result of their residual effect on human health; the need for the hour is to maintain hygienic practice in the storage systems.

\section{Author's Note}

Authors declare that there is no conflict of interest regarding the publication of this article. Authors confirmed that the data and the paper are free of plagiarism.

\section{Supporting Agencies}

The authors acknowledge the support of the Department of National Food Reserves, Federal Ministry of Agriculture and Rural Development, Nigeria for their cooperation.

\section{References}

Abramso D. 1991. Development of moulds, mycotoxins and odours in moist cereal during storage. Cereal Grain Development in Food Science (26): 119-146.

ATA. 2012. Agricultural Transformation Agenda, New Agricultural Policy Thrust. Published by the Federal Ministry of Agriculture and Rural Development. Nigeria. 4-34.

Ajisegiri ESA, Obafisoye JO. 2005. Training manual for in- plant Training of Strategic Grain Reserve Technical Staff. Department of Strategic Grain Reserve, Federal Ministry of Agriculture and Rural Development. Nigeria.

Alabadan BA. 2006. Evaluation of Wooden Silo during Storage of Maize (Zea mays) in Humid Tropical Climate. Agricultural Engineering International: CIGR E-journal. Manuscript BC 05 013. Vol. VIII. February, 2006.
Arthur FH, Throne JE, Maier D, Montross MD. 2001. Impact of Aeration on Maize Weevil (Coleoptera: curculionidae) Populations in Corn Stored in the Northern United States: Simulation Studies. American Entomologist, 47(2): 104-111, https://doi.org/10.1093/ae/47.2.104.

Asiedu EA, Van Gastel AGJ. 2001. Dehumidifying drying; a viable option for long term seed storage in humid tropics. Impact, challenges and prospects of maize research and development in West and Central Africa Workshop Proceedings. IITA- Cotonou. Benin.

Attia R. 1948. Typical methods of handling and storing grain in Egypt. In: Int. Meet. on Infestation of Foodstuffs. S. S. Easter, Ed. Agric. Stud. 2:105.

Banks HJ, Annis PC. 1980. Conversion of existing grain storage structures for modified atmosphere use. In Shejbal, J., ed. Controlled atmosphere storage of grains. Developments in Agricultural Engineering (1): 461-473. https://doi.org/10.1016/ B978-0-444-41939-2.50046-2.

Baral S, Hoffmann V. 2018. Tackling post- harvest loss in Ghana: Cost-effectiveness of technologies. Washington, D.C.: International Food Policy Research Institute (IFPRI). http://ebrary.ifpri.org/cdm/ref/collection/p15738coll2/id/132323

Bosomtwe A, Osekre EA, Opit G, Mbata G, Nsiah EP. 2020. Evaluation of Plastic and Steel Bins for Protection of Stored Maize Against Insect Infestation in Ghana. Journal of Global Agriculture and Ecology, 9(1):30-42. Retrieved from http://www.ikprress.org/index.php/JOGAE/article/view/4952.

Bothast RJ. 1978. Fungal deterioration and related phenomena in cereals, legumes and oilseeds. In: Postharvest Biology and Biotechnology, Ch. 8, pp. 210-243, Hultin, H.O. and Milner, M. (Eds.) Food and Nutrition Press Inc. Westport, Conn. USA.

Boxall RA. 1986. A critical review of the methodology for assessing farm-level grain losses after harvest. Report of the Tropical Development and Research Institute.:139-191.

Brunner H. 1989. Getreidepflege durch Kühlkonservierung, Technische Rundschau Sulzer, Heft 4, Gebrüder Sulzer AG Winterthur, Switzerland.

Calderon M, Barkai-Golan R. 1990. Food Preservation by Modified Atmospheres (1st Ed.), CRC Press, 416p.

Daudu CK, Awotide W, Fabiyi YL. 2013. Guaranteed Minimum Price (GMP) in Nigeria: Issues ad Options. Unpublished paper presented at NSGR Development and Review Committee meeting. Minna, Nigeria.

De Bruin T, Villers P, Wagh A. 2002. Navarro, S. Worldwide use of hermetic storage for the preservation of agricultural products. In Proceedings of the 9th International Controlled Atmosphere \& Fumigation Conference (CAF), Antalya, Turkey, 15-19 October 2012; pp. 1-8.

FAO. 1994. Food and Agriculture Organization, Maintenance and Operation of Bulk Grain Stores and Grain Storage Techniques: Evolution and Trends in Developing Countries. FAO Agricultural Services Bulletins 113 and 109. D.L. Proctor, Ed. FAO, Rome.

Girish SK. 1980. Studies on the preservation of foodstuffs under natural airtight storage. In: Proc. Int. Symposium on Controlled Atmosphere Storage of Grains. J. Shejbal, Ed. Elsevier, Amsterdam. pp. 15-24.

Greeley M. 1987. Postharvest Losses, Technology and Employment. The Case of Rice in Bangladesh. Boulder, Colorado: Westview Press, xviii. p. 345.

Hassan MM, Amupitan JO, Adebola DA. 2009. Food Security: Agriculture and Gender Relation in Post- Harvest Storage. African Regional Conference on Gender and the Millennium Development Goals. Book of Abstracts. Third World Organization for Women in Science (TWOWS). p. 66.

Hodges RJ, Buzby JC, Bennett B. 2011. Post-harvest losses and waste in developed and less developed countries: opportunities to improve resource use. Journal of Agricultural Science. 2011(149): 37-45, doi: 10.1017/S0021859610000936. 
Hodges R. 2013. Rural 21 Focus: Tackling post-harvest cereal losses in sub-Saharan Africa. Available: http://www.rural21.com/ uploads/media/rural2013_01-S16-18.pdf (Accessed on January $18,2020)$.

Holy B. 2008. Revised Standard Version. The British and Foreign Bible Society. Published by Bible Society Resource Limited. China. Genesis Chapters 36-44.

Igbeka JC. 1983. Evaluation of grain storage techniques in Nigeria. African Journal of Science and Technology (AJST) (2): 22-34. Nairobi, Kenya.

Igbeka JC. 2013. Agricultural processing and storage Engineering. ( $1^{\text {st }}$ ed.). Ibadan University Press, Nigeria. 99140.

Igbeka JC, Olumeko OO. 1996. An appraisal of village level grain storage practices in Nigeria. Journal of A.M.A, Tokyo. 27(I): 29-33.

Ileleji KE. 2010. Fundamental of Stored Grain Management. USNigerian Commodity Storage Workshop. Unpublished Training manual. Food Reserves and Storage Department, Federal Ministry of Agriculture and Rural Development, Nigeria. 1: 1-13.

Ileleji KE, McNeill S, Opit GP. 2009. Commodity Storage Assessment and Capacity Building needs in Nigeria. USDAFAS.

Jay E. 1984. Recent advances in the use of modified atmospheres for the control of stored product insects. In: Insect Management for Food Storage and Processing. F. Baur, ed. Am. Assoc. Cereal Chem., St. Paul, MN. 241-254.

Kamel AH. 1980. Underground storage in some Arab countries. In: Proc. Int. Symp. on Controlled Atmosphere Storage of Grains. J. Shejbal, Ed. Elsevier, Amsterdam. pp. 25-38.

Kiaya V. 2014. Post-harvest losses and strategies to reduce them. Technical paper on Post-Harvest Losses. Action Contre La Faim (ACF). http://www.academia.edu/download/45278162/ POST_HARVEST_LOSSES.pd p.22, Assessed on 17 May 2020.

Kimenju SC, de Groote H. 2010. Economic analysis of alternative maize storage technologies in Kenya; Proceedings of the Joint 3rd African Association of Agricultural Economists (AAAE) and 48th Agricultural Economists Association of South Africa (AEASA) Conference. Cape Town, South Africa, 1923 September 2010.

Maier DE, Ileleji KE, Woloshuk CPN. 2002. Detection of a developing hot spot in stored corn. Paper No 026075. Presented at the International Annual Meeting of the ASAE. St. Joseph, Mich. http://www.asae.org.

Mason LJ, Woloshu CP. 2010. Maximize grain quality \& profits using SLAM, in: S.L.A.M. Post-Harvest IPM. Purdue University Extension Service, ID-207, 1-3.

Mbata GN. 2013. Eradication of Global Hunger with Emphasis on Africa: Role in Post- Harvest Integrated Pest Management. Fulbright specialist lecture. The Federal University of Technology, Akure, Nigeria. 3- 17.

McNeill S. (2010). Moisture and Temperature Management of Grain and Grain Aeration. US- Nigerian Commodity Storage Workshop. Training manual. Food Reserve and Storage Department, Federal Ministry of Agriculture, Nigeria. 3:1- 13.

Mijinyawa Y. 2006. Farm Structures: Roles and Challenges in meeting the need of the Nigerian Farmers. Proceedings of Nigerian Institution of Agricultural Engineers. Vol. 28, 2006. 14- 19.

Mushira M. 2005. Manual on Grain Management and Equipment Maintenance in Silos. FAO project UTF/NIR: SPFS- Output 5. Unpublished training manual for storage managers. Strategic Grain Reserve Department, Federal Ministry of Agriculture and Rural Development. Nigeria.

NALEP. 2004. II Report No 6, Guidelines on Post- harvest and Grain Storage Management. Published by Plant Protection Services Branch. Ministry of Agriculture, Republic of Kenya in collaboration with NALEP.
Navarro S. 2006. Modified Atmospheres for the Control of Stored Product Insects and Mites. Chapter 11 in: Insect Management for Food Storage and Processing. Second Edition. J.W. Heaps ed. AACC International, St. Paul, USA.

Navarro S, Donahaye JE, Miriam R, Azrieli, A, Dia, R. 1999. Protecting grain without pesticides at farm level in the tropics. Pp. 353-363. In: Quality Assurance in Agricultural Produce. Johnson, G.I., To Le V., Duc, N.D., and Webb, M.C. (eds.) 19th ASEAN Seminar on Post-Harvest Technology, Ho Chi Min City, Vietnam 9-12 Nov 1999, ACIAR Proceedings NO. 100

Navarro S, Donahaye E, Silberstein B. 1988. Apparatus and method for storing grain. Israel Patent No. 87301.

Noyes RT, Kenkel P. 1993. Cost and Benefits of installing closed loop fumigation systems in commercial elevators, Proceedings of the International Working Conference on Stored-product Protection, Vol. 1 Stillwater, Oklahoma State University, Cooperative Extension Service, OSU Fact Sheet No. 219, 4p.

Noyes RT, Kenkel P, Tate G. 1995. Closed Loop Fumigation Systems. In Krischik, V., Cuperus, G., Galliart, D. (Eds.) Stored Product Management. Oklahoma State University, Stillwater, Cooperative Extension Services, 153-161.

Noyes R, Navarro S, Armitage D. 2002. Supplemental Aeration Systems. In The Mechanics and Physics of Modern Grain Aeration Management, 413-488 (Eds. S. Navarro and R. Noyes). Boca Raton, Fl. CRC Press.

Odigboh EU. 2004. Status of Agro- Processing in Nigeria. Invited plenary session paper at the Nigerian Institution of Agricultural Engineers International conference, Ilorin.

Okunade SO. 2013. Traditional Methods and Their Improvement in Post-Harvest Food Losses Reduction in Nigeria. Presented at a 3-Day Workshop On Reduction of Post- Harvest Food Losses in Nigeria. Workshop on Reduction of Post-Harvest Food Losses in Nigeria. Federal University of Technology, Akure, Nigeria.

Olorunfemi BJ. 2014. Computer aided Management of Grain Storage in Nigeria. Ph.D. thesis. Federal University of Agriculture, Abeokuta, Nigeria.

Olorunfemi BJ, Adejuyigbe SB, Adekunle AA. 2015. Development of Computer-aided Management for Grain Reception at grain storage silos in Nigeria, International Journal of Engineering and Applied Sciences. 2(7): 45-49.

Pomeranz Y, Christensen CM. 1982. Storage of cereal grains and their products. An association cereal chem., St Paul, Mn. 145215.

Rajashekar Y, Bakthavatsalam N, Shivanandappa T. 2012. Botanicals as grain protectants Psyche J. of Entomol., 2012 DOI:10.1155/2012/646740.

Roblodo ER. 2005. Manual on Storage Management and Quality Control. United Nations Development Programme/FAO Project MLN/85/018.

Sheahan M, Barrett CB. 2017. Review: Food loss and waste in Sub-Saharan Africa: A critical review. Food Policy Vol. 70, 1-12. https://doi.org/10.1016/j.foodpol.2017.03.012.

Shengbin L. 2006. Study on farm grain storage in China. In: Proceedings of the 9th International Working Conference on Stored-Product Protection, ABRAPOS, Passo Fundo, RS, Brazil, 15-18 October 2006.

Fox T, Fimeche C. 2013. Global food: wastes not, want not. Institution of Mechanical Engineers. England and Wales.

Talabi AE. 1996. Appropriate Storage Facilities for Promoting Economic Growth and Food Security. Bulletin of Nigerian Institute of Food Science and Technology. 17- 31.

Tefera T, Kanampiu F, De-Groote H, Hellin J, Kimenju SC, Beyene S, Boddupalli YPM, Shiferaw B, Banziger M. 2011. The metal silo: An effective grain storage technology for reducing post-harvest insect and pathogen losses in maize while improving smallholder farmers' food security in developing countries. Crop Protection 30 (3): 240-245. 
Tyler PS, Boxall RA. 1984. Post-harvest loss reduction programmes: a decade of activities: what consequences? Tropical Stored Products Information 50, 4-13.

Udoh JM, Cardwell KF, Ikotun T. 2000. Storage structure and aflatoxin content of maize in 5 agro eco logical Zones of Nigeria. J. Stored Prod. Res., 36(2): 187- 201.

UNIDO. 1979. United Nations Industrial Development Organization, Appropriate industrial technology for food storage and processing. UNIDO Monograph, No. 7, New York.

Warrick C. 2010. Grain aeration controllers. (Technical report), Kondinin group report. No 218, www.farmingahead.can.au.
WeiFen Q, ZuXun J. 2003. Paddy and rice storage in China. Advances in Stored Product Protection, Proceedings of the 8th International Working Conference on Stored Product Protection, CAB International; Wallingford, UK:26-39.

Williams SB, Baributsa D, Woloshuk C. 2014. Assessing Purdue Improved Crop Storage (PICS) bags to mitigate fungal growth and aflatoxin contamination. Journal of stored Products Research, Vol. 59(2014):190-196 .https:/doi.org/ 10.1016/j.jspr.2014.08.003. 